\title{
Resistance to Phytophthora citrophthora and $P$. parasitica and Nursery Characteristics of Several Citrus Rootstocks
}

\author{
M. E. Matheron, Extension Plant Pathologist, G. C. Wright, Extension Citrus Specialist, and M. Porchas, Re- \\ search Specialist, University of Arizona, Yuma Agricultural Center, Yuma 85364
}

\begin{abstract}
Matheron, M. E., Wright, G. C., and Porchas, M. 1998. Resistance to Phytophthora citrophthora and P. parasitica and nursery characteristics of several citrus rootstocks. Plant Dis. 82:12171225 .

Studies were conducted to compare existing and potential citrus rootstocks with respect to resistance to root rot and gummosis caused by Phytophthora citrophthora and P. parasitica in greenhouse and growth chamber experiments and horticultural performance under simulated nursery conditions. Depending upon rootstock and experiment, mean root weights resulting from inoculation with $P$. citrophthora were 27 to $96 \%$ lower than the comparable controls. In similar experiments with the same rootstocks, inoculation with $P$. parasitica resulted in root weights that were 38 to $95 \%$ less than weights of the noninoculated controls. During 1994 or 1995, mean root weight reduction compared with noninoculated plants among Citrus macrophylla, rough lemon, C. volkameriana, and Sunki mandarin $\times$ Flying Dragon trifoliate (62-109$19)$ attributable to $P$. citrophthora and mean root weight reduction among $C$. macrophylla, $C$. volkameriana, rough lemon, Sacaton citrumelo, Sunki mandarin $\times$ Flying Dragon trifoliate $(62-$ 109-19), African shaddock $\times$ Rubidoux trifoliate, and Shekwasha mandarin $\times$ English trifoliate attributable to $P$. parasitica were significantly less than those recorded for all other tested rootstocks. Rootstocks that sustained a low percentage of root weight reduction generally experienced a low percentage of shoot weight reduction and survived longer as well. In evaluation of resistance to gummosis, depending on rootstock and experiment, the mean length of stem lesions caused by $P$. citrophthora on rootstocks ranged from 0.2 to $25.0 \mathrm{~mm}$, whereas values for $P$. parasitica ranged from 0.2 to $18.5 \mathrm{~mm}$. Stem lesions smaller than $5 \mathrm{~mm}$ in length were recorded for 21 and 14 of 36 different rootstocks inoculated with P. citrophthora and P. parasitica, respectively. On the other hand, $P$. citrophthora and $P$. parasitica caused stem lesions of at least $10 \mathrm{~mm}$ in length on 8 and 16 citrus rootstocks, respectively. Desirable nursery characteristics, including vigorous growth, minimal branching, and high leaf chlorophyll content, were demonstrated most prominently by Gomiri rough lemon, C. volkameriana, and Benton citrange, and to a lesser degree by some other rootstocks. Possible factors that could account for inconsistent classification of some citrus rootstocks as susceptible or resistant to Phytophthora root rot and gummosis are discussed.
\end{abstract}

Phytophthora gummosis and root rot, which are among the most serious fungal diseases of citrus (17), can be caused by Phytophthora citrophthora and P. parasitica in the United States. Both fungi are cited as major citrus pathogens in nurseries and groves in Arizona (25) and California $(10,19)$, whereas $P$. parasitica alone is the primary pathogen in Florida (32) and Texas $(29,30)$.

In citrus nurseries and orchards, diseases due to Phytophthora can be prevented or minimized by avoiding overirrigation (34), facilitating soil drainage (34), using the systemic fungicides fosetyl-Al (Aliette, Rhone-Poulenc Ag Co., Research Triangle Park, NC) or metalaxyl (Ridomil, Novartis

Corresponding author: M. E. Matheron
E-mail: matheron@ag.arizona.edu

Accepted for publication 28 July 1998.

Publication no. D-1998-0824-02R

(C) 1998 The American Phytopathological Society tant hurdle a potential rootstock must overcome to become successful. Rootstocks should be vigorous, should exhibit minimal branching, and should be adaptable to the prevalent soil type. In Arizona, soil $\mathrm{pH}$ typically exceeds 8.0 (1), yet many trifoliate and some trifoliate hybrid rootstocks are not readily adaptable to these edaphic conditions $(8,28)$. Leaf chlorophyll content is a typical objective measurement of susceptibility to iron chlorosis at high soil $\mathrm{pH}$. Thus, the objectives of our research were to identify rootstocks that are resistant to Phytophthora spp., are adapted to typical alkaline soils of Arizona, and have superior nursery characteristics. An earlier report on a portion of this research has been published (24).

\section{MATERIALS AND METHODS}

Resistance to root rot. The citrus rootstocks and germ plasm (Table 1) were grown from seed in sterile potting mix (75\% peat: $25 \%$ vermiculite, $\mathrm{vol} / \mathrm{vol}$ ) within wooden flats $43 \mathrm{~cm}$ wide $\times 57 \mathrm{~cm}$ long $\times 19 \mathrm{~cm}$ high. Seedlings 6 to 14 months old were removed carefully from the potting mix and washed thoroughly in tap water to remove particles from the roots. Individual plants were placed in an 8 -cm-diameter $\times 13$-cm-deep plastic cup so that roots were totally immersed in $300 \mathrm{ml}$ of distilled water within each container. Five plants of each test rootstock were inoculated with agar disks bearing sporangia of $P$. citrophthora or $P$. parasitica using procedures described previously (22). Briefly, isolates of Phytophthora were grown on V8 juice agar (26), and 10 agar disks (6 $\mathrm{mm}$ diameter) were removed from the edge of an actively growing culture and incubated in nonsterile soil extract in 60$\mathrm{mm}$-diameter plastic petri dishes. Numerous sporangia formed after incubation for 6 days at $24^{\circ} \mathrm{C}$ and subsequently were induced to release zoospores by chilling for $15 \mathrm{~min}$ at $4^{\circ} \mathrm{C}$. Immediately after chilling, 10 agar disks bearing sporangia were added to each cup containing a plant. Barerooted plants were incubated in water containing sporangia to achieve uniform exposure of roots to zoospores emerging from sporangia. An additional five plants of each rootstock were not inoculated to serve as a control treatment. Plants within cups were maintained at $24^{\circ} \mathrm{C}$ in an illuminated incubator under a photosynthetic photon flux density (PPFD) of 53 to 74 $\mu \mathrm{E} \cdot \mathrm{m}^{-2} \cdot \mathrm{s}^{-1}$ with a 12 -h photoperiod for 48 
$\mathrm{h}$, with the agar disks remaining on the bottom of the cups during this time.

Inoculum was quantified by collecting 1 $\mathrm{ml}$ of water from five different cups containing a rootstock seedling $4 \mathrm{~h}$ after the addition of agar disks bearing sporangia of $P$. citrophthora or $P$. parasitica. The 1-ml sample then was evenly spread over the surface of pimaricin ampicillin rifampicin pentachloronitrobenzene (PARP) agar medium (16) in a 100 -mm-diameter petri dish. After incubation for 24 to $48 \mathrm{~h}$ at $24^{\circ} \mathrm{C}$, the number of colonies of Phytophthora on each plate was recorded to estimate the number of propagules of the pathogen per $\mathrm{ml}$ of water during the root inoculation period. The concentration of zoospores ranged from 25 to 250 and from 26 to 176 per $\mathrm{ml}$ of water for $P$. citrophthora and $P$. parasitica, respectively.

After the incubation period, seedlings were planted in peat:vermiculite potting mix within 10 -cm-diameter $\times 10$-cm-deep plastic pots and maintained in the greenhouse for 4 months. During this time, the number of individual plants that died was recorded weekly. To stimulate develop- ment of Phytophthora root rot, each pot containing a rootstock was placed in a plastic container and filled with water for 48 h every 2 weeks. Plants were watered as needed between periods of flooding. At the end of each trial, the fresh weight of each plant shoot and root system was recorded. Percent reduction of root and shoot weight due to $P$. citrophthora and $P$. parasitica was derived by dividing the shoot or root weight of each inoculated seedling with the mean shoot or root weight of the five noninoculated seedlings of the same type. Two separate experiments evaluated 19 different rootstocks in 1994, and 28 rootstocks were examined in two separate trials in 1995. All trials were terminated 120 days after inoculation of rootstocks. Air and soil temperatures were recorded hourly in the greenhouse for the duration of these trials using thermistor probes (Ryan Instruments, Redmond, WA).

Resistance to gummosis. Seedlings of citrus rootstocks (Table 1) were grown and prepared for inoculation as described earlier. At 4 to 27 months of age, five seedlings of each test rootstock were inoculated by removing a 4-mm-diameter disk of bark from the stem of each plant and placing a V8 juice agar disk bearing mycelium of $P$. citrophthora or $P$. parasitica on the circular wound. Noninoculated control plants received a V8 juice agar disk without mycelium. The agar disk was held in place with plastic tape. Plants then were placed into wide-mouth 2-liter glass flasks containing enough water $(1,800 \mathrm{ml})$ to cover plant roots. Portions of plant stems containing the agar disks were above the surface of the water but within the flask. Cotton was placed in the mouth of each flask around the stems of plants to help maintain high relative humidity within each flask. Plants within flasks were incubated for 12 days at $21^{\circ} \mathrm{C}$ in an illuminated incubator under a PPFD of 53 to $74 \mu \mathrm{E} \cdot \mathrm{m}^{-2} \cdot \mathrm{s}^{-1}$ with a $12-\mathrm{h}$ photoperiod, after which the length of resultant cankers was recorded. Two separate experiments were conducted in each of three different years; 6,25 , and 24 rootstocks were evaluated during 1993, 1994, and 1996, respectively.

Data from the two experiments conducted each year were pooled since experimental variances were homogeneous according to Bartletts Test. Values obtained

Table 1. Citrus rootstocks tested for resistance to root rot and gummosis caused by Phytophthora citrophthora and P. parasitica

\begin{tabular}{|c|c|c|}
\hline Genus and species & Cultivar $^{\mathrm{y}}$ & Source $^{\mathrm{z}}$ \\
\hline \multirow[t]{5}{*}{ Citrus aurantium } & Goutou no. 1 sour orange* & FCBPP \\
\hline & Oklawaha sour orange* & YMAC \\
\hline & Smooth Flat Seville* & FCBPP \\
\hline & sour orange & YMAC \\
\hline & Zhu Luan* & FCBPP \\
\hline \multirow[t]{3}{*}{ C. aurantium $\times$ C. reshni } & Savage sour orange $\times$ Cleopatra mandarin no. $1(63-191-22)^{*}$ & USDA-Indio \\
\hline & Savage sour orange $\times$ Cleopatra mandarin no. $2(63-191-69)^{*}$ & USDA-Indio \\
\hline & Sicilian sour orange $\times$ Cleopatra mandarin no. $2(\mathrm{~F}-163-192-51)$ & USDA-Indio \\
\hline C. depressa $\times$ Poncirus trifoliata & Shekwasha mandarin $\times$ English trifoliate $(62-137-2)^{*}$ & USDA-Indio \\
\hline \multirow{4}{*}{$\begin{array}{l}\text { C. jambhiri } \\
\text {. jolla }\end{array}$} & Gomiri rough lemon $(62-437-501) *$ & USDA-Indio \\
\hline & Milam rough lemon* & USDA-Indio \\
\hline & Soh Jalia rough lemon (58-329-502)* & USDA-Indio \\
\hline & rough lemon & YMAC \\
\hline C. limonia $\times$ C. depressa & Rangpur lime $\times$ Shekwasha mandarin $(61-169-2)^{*}$ & USDA-Indio \\
\hline C. limonia $\times$ C. maxima $(C$. grandis $)$ & Rangpur lime $\times$ Kao Phung shaddock (pummelo) $(59-121-15) *$ & USDA-Indio \\
\hline \multirow[t]{2}{*}{ C. limonia $\times$ P. trifoliata } & Rangpur lime $\times$ Marks trifoliate $(\mathrm{RN}-94-22)$ & UC Riverside \\
\hline & Rangpur lime $\times$ Marks trifoliate $(\mathrm{RN}-94-23)$ & UC Riverside \\
\hline C. macrophylla & Citrus macrophylla & YMAC \\
\hline C. maxima $\times P$. trifoliata & African shaddock $\times$ Rubidoux trifoliate* & USDA-Indio \\
\hline C. maxima $\times(P$. trifoliata $\times C$. paradisi $)$ & Kao Pan shaddock $\times$ Swingle citrumelo $(55-21-2)^{*}$ & USDA-Indio \\
\hline C. obovoidea & Citrus obovoidea & FCBPP \\
\hline C. paradisi & CRC 343 grapefruit* & USDA-Indio \\
\hline C. reshni & Cleopatra mandarin* & FCBPP \\
\hline C. reticulata & Sun Chu Sha mandarin* & FCBPP \\
\hline \multirow{2}{*}{ C. reticulata $\times P$. trifoliata } & Sunki mandarin $\times$ Flying Dragon trifoliate $(62-109-19)^{*}$ & USDA-Indio \\
\hline & Sunki mandarin $\times$ Flying Dragon trifoliate $(\mathrm{RN}-94-20)$ & UC Riverside \\
\hline C. sinensis & Pineapple sweet orange & YMAC \\
\hline \multirow[t]{4}{*}{ C. sinensis $\times P$. trifoliata } & Benton citrange* & FCBPP \\
\hline & C-35 citrange* & Willits and Newcomb \\
\hline & Carrizo citrange* & Willits and Newcomb \\
\hline & Troyer citrange & YMAC \\
\hline C. taiwanica & Nansho daidai & YMAC \\
\hline C. volkameriana & Citrus volkameriana* & YMAC \\
\hline P. trifoliata & Rich 16-6 trifoliate & Willits and Newcomb \\
\hline P. trifoliata $\times C$. aurantium & Citremon 1449 & YMAC \\
\hline \multirow{3}{*}{$P$. trifoliata $\times C$. paradisi } & Citrumelo 4475 (Swingle)* & Willits and Newcomb \\
\hline & Citrumelo $80-8^{*}$ & FCBPP \\
\hline & Sacaton citrumelo (56-70-2)* & USDA-Indio \\
\hline
\end{tabular}

${ }^{\mathrm{y}}$ Cultivars marked with an asterisk were included in the field portion of the study.

${ }^{\mathrm{z}}$ FCBPP = Florida Citrus Budwood Protection Program; YMAC = Yuma Mesa Agricultural Center; USDA-Indio = U.S. Date and Citrus Station, Indio, CA; UC Riverside = University of California Citrus Research Station, Riverside; Willits and Newcomb, Arvin, CA. Numbers in parentheses following cultivars from USDA-Indio correspond to original accession numbers for these selections. 
from each root rot and gummosis trial were analyzed by analysis of variance (ANOVA) (SigmaStat), and the Duncan-Waller $k$-ratio (LSD) test was used to compare treatment means. Linear regression was used to determine possible significant relationships between reduction in root weight and reduction in shoot weight or plant survival time.

Nursery characteristics of citrus rootstocks. Approximately 150 seeds of each cultivar marked with an asterisk in Table 1 were selected for the field trial. Seeds were soaked for 5 days according to the method of Chilembwe et al. (7) prior to planting.
Seeds were planted in the field nursery at the Yuma Mesa Agricultural Center in May 1996. Soil type was Superstition sand with $\mathrm{pH}$ 8.2. Emergence time was 4 to 6 weeks. Seedlings were then irrigated and fertilized according to typical industry standards for southwest Arizona. There were 10 blocks of seedlings arranged in a randomized complete block experimental design. In May 1997, 50 seedlings of each cultivar were evaluated for growth, degree of branching, and leaf chlorophyll. For branching, a visual estimate was made of the percentage of total stem nodes that exhibited lateral branching. Leaf chloro- phyll was determined using a SPAD 502 portable chlorophyll meter (Minolta Corp., Ramsey, NJ), which nondestructively estimates chlorophyll $\mathrm{a}$ and $\mathrm{b}$ concentration in relative units. Three fully expanded leaves were measured from each plant. Five leaves with incremental chlorophyll levels (determined by SPAD 502 readings) were then harvested to construct a standard curve for quantification of chlorophyll content. One $1.0 \mathrm{~cm}^{2}$ disk was removed from each leaf. Chlorophyll was extracted using $\mathrm{N}, \mathrm{N}$-dimethyl-formamide; then chlorophyll concentration of each disk was calculated from the equation developed by

Table 2. Percent reduction of root and shoot weight and plant survival of citrus rootstocks inoculated with zoospores of Phytophthora citrophthora ${ }^{\mathrm{x}}$

\begin{tabular}{|c|c|c|c|c|c|c|}
\hline \multirow[b]{3}{*}{ Rootstock } & \multicolumn{6}{|c|}{ Percent reduction } \\
\hline & \multicolumn{2}{|c|}{ Root weight $^{\mathbf{y}}$} & \multicolumn{2}{|c|}{ Shoot weight ${ }^{y}$} & \multicolumn{2}{|c|}{ Plant survival $^{\mathrm{z}}$} \\
\hline & 1994 & 1995 & 1994 & 1995 & 1994 & 1995 \\
\hline \multicolumn{7}{|l|}{ Lemon types } \\
\hline Citrus macrophylla & $27 \mathrm{a}$ & $\ldots$ & $26 \mathrm{a}$ & $\ldots$ & $2 \mathrm{a}$ & $\ldots$ \\
\hline Rough lemon & $31 \mathrm{a}$ & $37 \mathrm{a}$ & $31 \mathrm{a}$ & $51 \mathrm{ab}$ & $16 \mathrm{a}-\mathrm{c}$ & $10 \mathrm{a}$ \\
\hline C. volkameriana & $33 \mathrm{a}$ & $71 \mathrm{~b}-\mathrm{f}$ & $40 \mathrm{ab}$ & $76 \mathrm{~d}-\mathrm{i}$ & $16 \mathrm{a}-\mathrm{c}$ & $39 \mathrm{c}-\mathrm{f}$ \\
\hline Soh Jalia rough lemon (58-329-502) & $\ldots$ & $70 \mathrm{~b}-\mathrm{e}$ & $\ldots$ & $67 \mathrm{c}-\mathrm{e}$ & $\ldots$ & $24 \mathrm{a}-\mathrm{d}$ \\
\hline Gomiri rough lemon (62-437-501) & $\ldots$ & $74 \mathrm{c}-\mathrm{g}$ & $\ldots$ & $73 \mathrm{~d}-\mathrm{h}$ & $\ldots$ & $37 b-f$ \\
\hline Milam rough lemon & $\ldots$ & $92 \mathrm{~h}-\mathrm{j}$ & $\ldots$ & 79 e-k & $\ldots$ & $70 \mathrm{j}$ \\
\hline \multicolumn{7}{|l|}{ Trifoliate and trifoliate hybrid types } \\
\hline Sunki mandarin $\times$ Flying Dragon trifoliate $(\mathrm{RN}-94-20)$ & $66 \mathrm{~b}$ & $\ldots$ & $67 \mathrm{c}-\mathrm{f}$ & $\ldots$ & $8 a-b$ & \\
\hline Troyer citrange & $66 \mathrm{~b}$ & $\ldots$ & $72 \mathrm{~d}-\mathrm{g}$ & $\ldots$ & $45 \mathrm{~d}-\mathrm{e}$ & $\ldots$ \\
\hline Rangpur lime $\times$ Marks trifoliate $(\mathrm{RN}-94-22)$ & $87 \mathrm{~d}$ & $\ldots$ & $85 \mathrm{~g}$ & $\ldots$ & $47 \mathrm{~d}-\mathrm{f}$ & $\ldots$ \\
\hline Sunki mandarin $\times$ Flying Dragon trifoliate (62-109-19) & $43 \mathrm{a}$ & $81 \mathrm{~d}-\mathrm{i}$ & $53 \mathrm{bc}$ & $42 \mathrm{a}$ & $15 \mathrm{a}-\mathrm{c}$ & $22 \mathrm{a}-\mathrm{d}$ \\
\hline Sacaton citrumelo $(56-70-2)$ & $75 \mathrm{~b}-\mathrm{d}$ & $87 \mathrm{~g}-\mathrm{j}$ & $60 \mathrm{~cd}$ & $68 \mathrm{c}-\mathrm{f}$ & $72 \mathrm{gh}$ & $9 \mathrm{a}$ \\
\hline C-35 citrange & $79 \mathrm{~b}-\mathrm{d}$ & $91 \mathrm{~h}-\mathrm{j}$ & $81 \mathrm{fg}$ & $88 \mathrm{i}-\mathrm{k}$ & $51 \mathrm{fg}$ & $44 \mathrm{~d}-\mathrm{g}$ \\
\hline Carrizo citrange & $89 \mathrm{~d}$ & $92 \mathrm{~h}-\mathrm{j}$ & $84 \mathrm{~g}$ & $83 \mathrm{f}-\mathrm{k}$ & $38 \mathrm{c}-\mathrm{e}$ & $27 \mathrm{a}-\mathrm{d}$ \\
\hline Kao Pan shaddock $\times$ Swingle trifoliate $(55-21-2)$ & $\ldots$ & $56 \mathrm{~b}$ & $\ldots$ & $57 \mathrm{bc}$ & $\ldots$ & $9 \mathrm{a}$ \\
\hline Shekwasha mandarin $\times$ English trifoliate $(62-137-2)$ & $\ldots$ & $60 \mathrm{bc}$ & $\ldots$ & $66 \mathrm{c}-\mathrm{e}$ & $\ldots$ & $13 \mathrm{a}$ \\
\hline Rich $16-6$ trifoliate & $\ldots$ & $81 \mathrm{~d}-\mathrm{i}$ & $\ldots$ & $66 \mathrm{c}-\mathrm{e}$ & $\ldots$ & $54 \mathrm{f}-\mathrm{i}$ \\
\hline Benton citrange & $\ldots$ & $84 \mathrm{e}-\mathrm{j}$ & $\ldots$ & $83 \mathrm{~g}-\mathrm{k}$ & $\ldots$ & $12 \mathrm{a}$ \\
\hline Citrumelo $80-8$ & $\ldots$ & $84 \mathrm{e}-\mathrm{j}$ & $\ldots$ & $56 \mathrm{a}-\mathrm{c}$ & $\ldots$ & $9 \mathrm{a}$ \\
\hline African shaddock $\times$ Rubidoux trifoliate & $\ldots$ & $86 \mathrm{f}-\mathrm{j}$ & $\ldots$ & $70 \mathrm{c}-\mathrm{g}$ & $\ldots$ & $58 \mathrm{f}-\mathrm{j}$ \\
\hline Citrumelo 4475 & $\ldots$ & $91 \mathrm{~h}-\mathrm{j}$ & $\ldots$ & $86 \mathrm{~h}-\mathrm{k}$ & $\ldots$ & $8 \mathrm{a}$ \\
\hline \multicolumn{7}{|l|}{ Sour and sweet orange types } \\
\hline Sour orange & $76 \mathrm{~b}-\mathrm{d}$ & $\ldots$ & $79 \mathrm{e}-\mathrm{g}$ & $\ldots$ & $72 \mathrm{gh}$ & $\ldots$ \\
\hline Oklawaha sour orange & $80 \mathrm{~b}-\mathrm{d}$ & $\ldots$ & $65 \mathrm{c}-\mathrm{e}$ & $\ldots$ & $69 \mathrm{f}-\mathrm{h}$ & $\ldots$ \\
\hline Pineapple sweet orange & $86 \mathrm{~cd}$ & $\ldots$ & $75 \mathrm{~d}-\mathrm{g}$ & $\ldots$ & $88 \mathrm{~h}$ & $\ldots$ \\
\hline Goutou no. 1 sour orange & $\ldots$ & $67 b-d$ & $\ldots$ & $62 \mathrm{~b}-\mathrm{d}$ & $\ldots$ & 28 a-e \\
\hline Zhu Luan sour orange & $\ldots$ & $89 \mathrm{~g}-\mathrm{j}$ & $\ldots$ & $84 \mathrm{~g}-\mathrm{k}$ & $\ldots$ & $25 \mathrm{a}-\mathrm{d}$ \\
\hline Smooth flat Seville sour orange & $\ldots$ & $92 \mathrm{~h}-\mathrm{j}$ & $\ldots$ & $85 \mathrm{~h}-\mathrm{k}$ & $\ldots$ & $51 \mathrm{e}-\mathrm{h}$ \\
\hline \multicolumn{7}{|l|}{ Grapefruit and pummelo hybrid types } \\
\hline Rangpur lime $\times$ Kao Phuang shaddock (59-121-15) & $79 \mathrm{~b}-\mathrm{d}$ & $89 \mathrm{~g}-\mathrm{j}$ & $70 \mathrm{~d}-\mathrm{g}$ & $80 \mathrm{f}-\mathrm{k}$ & $70 \mathrm{f}-\mathrm{h}$ & $53 \mathrm{f}-\mathrm{i}$ \\
\hline CRC 343 grapefruit & $\ldots$ & $96 \mathrm{j}$ & $\ldots$ & $89 \mathrm{i}-\mathrm{k}$ & $\ldots$ & $68 \mathrm{~h}-\mathrm{j}$ \\
\hline \multicolumn{7}{|l|}{ Mandarin and mandarin hybrid types } \\
\hline Rangpur lime $\times$ Shekwasha mandarin $(61-169-2)$ & $68 \mathrm{bc}$ & $62 \mathrm{bc}$ & $76 \mathrm{e}-\mathrm{g}$ & $57 \mathrm{bc}$ & $53 \mathrm{e}-\mathrm{g}$ & $16 \mathrm{ab}$ \\
\hline Savage sour $\times$ Cleopatra mandarin no. $1(63-191-22)$ & $77 \mathrm{~b}-\mathrm{d}$ & $92 \mathrm{~h}-\mathrm{j}$ & $66 \mathrm{c}-\mathrm{f}$ & 89 i-k & $41 \mathrm{de}$ & $58 \mathrm{f}-\mathrm{j}$ \\
\hline Savage sour orange $\times$ Cleopatra mandarin no. $2(63-191-69)$ & $\ldots$ & $86 \mathrm{f}-\mathrm{j}$ & $\ldots$ & $77 \mathrm{e}-\mathrm{j}$ & $\ldots$ & $72 \mathrm{~h}-\mathrm{j}$ \\
\hline Cleopatra mandarin & $\ldots$ & $88 \mathrm{~g}-\mathrm{j}$ & $\ldots$ & $91 \mathrm{jk}$ & $\ldots$ & $72 \mathrm{~h}-\mathrm{j}$ \\
\hline Sicilian sour orange $\times$ Cleopatra mandarin no. $2($ F-163-192-51) & $\ldots$ & $95 \mathrm{i}-\mathrm{j}$ & $\ldots$ & $93 \mathrm{k}$ & $\ldots$ & $74 \mathrm{ij}$ \\
\hline Sun Chu Sha mandarin & $\ldots$ & $96 \mathrm{j}$ & $\cdots$ & $88 \mathrm{i}-\mathrm{k}$ & $\cdots$ & $62 \mathrm{~g}-\mathrm{j}$ \\
\hline \multicolumn{7}{|l|}{ Miscellaneous } \\
\hline C. taiwanica & $68 \mathrm{bc}$ & $\ldots$ & $73 \mathrm{~d}-\mathrm{g}$ & $\ldots$ & $52 \mathrm{~d}-\mathrm{g}$ & $\ldots$ \\
\hline Citremon 1449 & $78 \mathrm{~b}-\mathrm{d}$ & $\ldots$ & $67 \mathrm{c}-\mathrm{f}$ & $\ldots$ & $28 \mathrm{~b}-\mathrm{d}$ & $\ldots$ \\
\hline Mean & 67 & 81 & 65 & 74 & 44 & 38 \\
\hline $\operatorname{LSD}(P=0.05)$ & 19 & 15 & 16 & 14 & 29 & 27 \\
\hline
\end{tabular}

${ }^{\mathrm{x}}$ Each value is the mean of five replicate plants from each of two different experiments conducted in 1994 or 1995 . Citrus rootstocks in 1994 and 1995 were 5 to 11 and 5 to 6 months old, respectively, at the beginning of each trial. Numbers in each column with a different letter are significantly different $(P=0.05)$ according to the Duncan-Waller $k$-ratio (LSD) test.

y Percent reduction of root and shoot weight was determined by comparing the fresh weight of roots or shoots of each rootstock inoculated with $P$. citrophthora to that of the average root or shoot fresh weight of noninoculated plants of the same rootstock.

${ }^{\mathrm{z}}$ Percent reduction of plant survival was determined by comparing the time in days from planting in potting mix to death of each rootstock inoculated with $P$. citrophthora to the survival time of noninoculated plants of the same rootstock. Experiments were terminated 120 days after inoculation of rootstocks, and all noninoculated plants were alive at that time. 
Moran (27): Extractable chlorophyll $(\mathrm{mg} /$ liter $\left.)=20.27 \times A_{647}\right)+\left(7.04 \times A_{664}\right)$, where $A_{647}$ and $A_{664}$ refer, respectively, to absorbance at wavelengths of 647 and 664 $\mathrm{nm}$ measured in a spectrophotometer. Absorbance of leaf extracts was measured using a Perkin-Elmer Spec-20 spectrophotometer. Chlorophyll concentration was expressed on a leaf weight basis, and the standard curve was calculated using the regression equation: Total chlorophyll $(\mathrm{mg} / \mathrm{g}$ f.w. $)=3.3^{-7}+(0.0408 \times \mathrm{SPAD}$ reading) $R^{2}=0.85$. When ANOVA indicated significant effects of rootstock as a factor, pairwise multiple comparisons of means were accomplished with the Duncan-Waller $k$-ratio (LSD) test.

\section{RESULTS}

Resistance to root rot. Depending upon rootstock and experiment, mean root weights resulting from inoculation by $P$. citrophthora were 27 to $96 \%$ lower than the comparable controls. During 1994 or 1995 , mean root weight reduction compared with noninoculated seedlings among Citrus macrophylla, rough lemon, $C$. volkameriana, and Sunki mandarin $\times$ Flying Dragon trifoliate (62-109-19) was significantly less than that recorded for all other tested rootstocks. Mean shoot weights of seedlings inoculated with $P$. citrophthora were 26 to $93 \%$ lower than corresponding controls. The average reduction in time of survival during the same years for rootstocks inoculated with $P$. citrophthora ranged from 2 to $88 \%$ less than comparable control plants (Table 2).

Mean weights of roots resulting from inoculation by $P$. parasitica were 38 to 95\% lower than comparable controls. During 1994 or 1995, mean root weight reduction compared with noninoculated seedlings among C. macrophylla, C. volkameriana, rough lemon, Sacaton citrumelo,

Table 3. Percent reduction of root and shoot weight and plant survival of citrus rootstocks inoculated with zoospores of Phytophthora parasitica ${ }^{\mathrm{x}}$

\begin{tabular}{|c|c|c|c|c|c|c|}
\hline \multirow[b]{3}{*}{ Rootstock } & \multicolumn{6}{|c|}{ Percent reduction } \\
\hline & \multicolumn{2}{|c|}{ Root weight $^{\mathbf{y}}$} & \multicolumn{2}{|c|}{ Shoot weight ${ }^{y}$} & \multicolumn{2}{|c|}{ Plant survival $^{\mathrm{z}}$} \\
\hline & 1994 & 1995 & 1994 & 1995 & 1994 & 1995 \\
\hline \multicolumn{7}{|l|}{ Lemon types } \\
\hline Citrus macrophylla & $38 \mathrm{a}$ & $\ldots$ & $32 \mathrm{a}$ & $\cdots$ & $18 \mathrm{ab}$ & $\ldots$ \\
\hline C. volkameriana & $51 \mathrm{ab}$ & $91 \mathrm{f}-\mathrm{h}$ & $43 \mathrm{ab}$ & $85 \mathrm{i}-\mathrm{k}$ & $13 \mathrm{a}$ & $29 \mathrm{~d}-\mathrm{i}$ \\
\hline Rough lemon & $72 \mathrm{c}-\mathrm{e}$ & $64 \mathrm{ab}$ & $71 \mathrm{c}-\mathrm{g}$ & 54 a-d & $34 \mathrm{a}-\mathrm{d}$ & $0 \mathrm{a}$ \\
\hline Milam rough lemon & $\ldots$ & $73 \mathrm{bc}$ & $\ldots$ & $61 \mathrm{~b}-\mathrm{f}$ & $\ldots$ & $39 \mathrm{~h}-\mathrm{k}$ \\
\hline Soh Jalia rough lemon (58-329-502) & $\ldots$ & $76 \mathrm{~b}-\mathrm{e}$ & $\ldots$ & $61 \mathrm{~b}-\mathrm{f}$ & $\ldots$ & $9 \mathrm{ac}$ \\
\hline Gomiri rough lemon $(62-437-501)$ & $\ldots$ & $93 \mathrm{gh}$ & $\ldots$ & $91 \mathrm{k}$ & $\ldots$ & $32 \mathrm{f}-\mathrm{j}$ \\
\hline \multicolumn{7}{|l|}{ Trifoliate and trifoliate hybrid types } \\
\hline Troyer citrange & $68 \mathrm{~b}-\mathrm{d}$ & $\ldots$ & $67 \mathrm{c}-\mathrm{f}$ & $\ldots$ & $32 \mathrm{a}-\mathrm{d}$ & $\ldots$ \\
\hline Sunki mandarin $\times$ Flying Dragon trifoliate $(\mathrm{RN}-94-20)$ & $80 \mathrm{~d}-\mathrm{f}$ & $\ldots$ & $76 \mathrm{c}-\mathrm{g}$ & $\ldots$ & 35 a-e & $\ldots$ \\
\hline Rangpur lime $\times$ Marks trifoliate $(\mathrm{RN}-94-22)$ & $86 \mathrm{~d}-\mathrm{f}$ & $\ldots$ & $78 \mathrm{~d}-\mathrm{g}$ & $\ldots$ & $43 \mathrm{c}-\mathrm{f}$ & $\ldots$ \\
\hline Sacaton citrulemo $(56-70-2)$ & $47 \mathrm{a}$ & $73 \mathrm{bc}$ & $42 \mathrm{ab}$ & $45 \mathrm{a}$ & $27 \mathrm{bc}$ & $0 \mathrm{a}$ \\
\hline Sunki mandarin $\times$ Flying Dragon trifoliate $(62-109-19)$ & $54 \mathrm{a}-\mathrm{c}$ & $73 \mathrm{bc}$ & $56 \mathrm{bc}$ & $52 \mathrm{a}-\mathrm{c}$ & $18 \mathrm{ab}$ & $0 \mathrm{a}$ \\
\hline C-35 citrange & $73 \mathrm{de}$ & $82 \mathrm{c}-\mathrm{h}$ & $81 \mathrm{e}-\mathrm{g}$ & $70 \mathrm{e}-\mathrm{i}$ & $35 \mathrm{a}-\mathrm{d}$ & $5 \mathrm{ab}$ \\
\hline Carrizo citrange & $83 \mathrm{~d}-\mathrm{f}$ & $77 \mathrm{~b}-\mathrm{f}$ & $79 \mathrm{~d}-\mathrm{g}$ & $53 \mathrm{a}-\mathrm{d}$ & $40 \mathrm{~b}-\mathrm{e}$ & $0 \mathrm{a}$ \\
\hline African shaddock $\times$ Rubidoux trifoliate & $\ldots$ & $59 \mathrm{a}$ & $\ldots$ & $52 \mathrm{a}-\mathrm{c}$ & $\ldots$ & $38 \mathrm{~h}-\mathrm{k}$ \\
\hline Shekwasha mandarin $\times$ English trifoliate $(62-137-2)$ & $\ldots$ & $71 \mathrm{a}-\mathrm{c}$ & $\ldots$ & $62 \mathrm{c}-\mathrm{g}$ & $\ldots$ & $12 \mathrm{a}-\mathrm{e}$ \\
\hline Rich 16-6 trifoliate & $\ldots$ & $75 \mathrm{~b}-\mathrm{d}$ & $\ldots$ & 58 a-e & $\ldots$ & $20 \mathrm{a}-\mathrm{g}$ \\
\hline Kao Pan shaddock $\times$ Swingle trifoliate $(55-21-2)$ & $\ldots$ & $77 \mathrm{~b}-\mathrm{e}$ & $\ldots$ & $68 \mathrm{~d}-\mathrm{h}$ & $\ldots$ & $28 \mathrm{~b}-\mathrm{h}$ \\
\hline Benton citrange & $\ldots$ & $80 \mathrm{c}-\mathrm{g}$ & $\ldots$ & $78 \mathrm{~h}-\mathrm{k}$ & $\ldots$ & $2 a$ \\
\hline Citrumelo 80-8 & $\ldots$ & $82 \mathrm{c}-\mathrm{h}$ & $\ldots$ & $47 \mathrm{ab}$ & $\ldots$ & $12 \mathrm{a}-\mathrm{f}$ \\
\hline Citrumelo 4475 & $\ldots$ & $82 \mathrm{c}-\mathrm{h}$ & $\ldots$ & 54 a-d & $\ldots$ & $0 \mathrm{a}$ \\
\hline \multicolumn{7}{|l|}{ Sour and sweet orange types } \\
\hline Pineapple sweet orange & $72 \mathrm{c}-\mathrm{e}$ & $\ldots$ & $79 \mathrm{~d}-\mathrm{g}$ & $\ldots$ & $74 \mathrm{gh}$ & $\ldots$ \\
\hline Oklawaha sour orange & $78 \mathrm{~d}-\mathrm{f}$ & $\ldots$ & $61 \mathrm{~b}-\mathrm{e}$ & $\ldots$ & $48 \mathrm{c}-\mathrm{f}$ & $\ldots$ \\
\hline Sour orange & $82 \mathrm{~d}-\mathrm{f}$ & $\ldots$ & $72 \mathrm{c}-\mathrm{g}$ & . & $86 \mathrm{~h}$ & $\ldots$ \\
\hline Zhu Luan sour orange & $\ldots$ & $78 \mathrm{c}-\mathrm{f}$ & $\ldots$ & 59 a-e & $\ldots$ & $0 \mathrm{a}$ \\
\hline Smooth Flat Seville sour orange & $\ldots$ & $84 \mathrm{c}-\mathrm{h}$ & $\ldots$ & $74 \mathrm{f}-\mathrm{j}$ & $\ldots$ & $8 \mathrm{a}-\mathrm{c}$ \\
\hline Goutou no. 1 sour orange & $\ldots$ & $89 \mathrm{~d}-\mathrm{h}$ & $\ldots$ & $79 \mathrm{~h}-\mathrm{k}$ & $\ldots$ & 11 a-e \\
\hline \multicolumn{7}{|l|}{ Grapefruit and pummelo hybrid types } \\
\hline Rangpur lime $\times$ Kao Phung shaddock $(59-121-15)$ & $75 \mathrm{~d}-\mathrm{f}$ & $84 \mathrm{c}-\mathrm{h}$ & $59 \mathrm{~b}-\mathrm{d}$ & $66 \mathrm{c}-\mathrm{h}$ & $50 \mathrm{~d}-\mathrm{f}$ & $31 e-j$ \\
\hline CRC 343 grapefruit & $\ldots$ & $84 \mathrm{c}-\mathrm{h}$ & $\ldots$ & $70 \mathrm{e}-\mathrm{i}$ & $\ldots$ & $1 \mathrm{a}$ \\
\hline \multicolumn{7}{|l|}{ Mandarin and mandarin hybrid types } \\
\hline Rangpur lime $\times$ Shekwasha mandarin $(61-169-2)$ & 88 ef & $91 \mathrm{f}-\mathrm{h}$ & $91 \mathrm{~g}$ & $81 \mathrm{~h}-\mathrm{k}$ & $82 \mathrm{gh}$ & $14 \mathrm{a}-\mathrm{f}$ \\
\hline Savage sour orange $\times$ Cleopatra mandarin no. $1(63-191-22)$ & $88 \mathrm{ef}$ & $95 \mathrm{~h}$ & $82 \mathrm{fg}$ & $90 \mathrm{jk}$ & $66 \mathrm{f}-\mathrm{h}$ & $54 \mathrm{k}$ \\
\hline Cleopatra mandarin & $\ldots$ & $87 \mathrm{~d}-\mathrm{h}$ & $\ldots$ & $80 \mathrm{~h}-\mathrm{k}$ & $\ldots$ & $34 \mathrm{~g}-\mathrm{k}$ \\
\hline Savage sour orange $\times$ Cleopatra mandarin no. $2(63-191-69)$ & $\ldots$ & $88 \mathrm{~d}-\mathrm{h}$ & $\ldots$ & $78 \mathrm{~g}-\mathrm{k}$ & $\ldots$ & $52 \mathrm{jk}$ \\
\hline Sun Chu Sha mandarin & $\ldots$ & $89 \mathrm{~d}-\mathrm{h}$ & $\ldots$ & $66 \mathrm{c}-\mathrm{h}$ & $\ldots$ & $8 \mathrm{a}-\mathrm{c}$ \\
\hline Sicilian sour orange $\times$ Cleopatra mandarin no. $2(\mathrm{~F}-163-192-51)$ & $\ldots$ & $92 \mathrm{gh}$ & $\ldots$ & $86 \mathrm{j}-\mathrm{k}$ & $\ldots$ & $49 \mathrm{i}-\mathrm{k}$ \\
\hline \multicolumn{7}{|l|}{ Miscellaneous } \\
\hline C. taiwanica & $79 \mathrm{~d}-\mathrm{f}$ & $\ldots$ & $78 \mathrm{~d}-\mathrm{g}$ & $\ldots$ & $49 \mathrm{c}-\mathrm{f}$ & $\ldots$ \\
\hline Citremon 1449 & 89 ef & $\ldots$ & $80 \mathrm{e}-\mathrm{g}$ & $\ldots$ & $48 \mathrm{c}-\mathrm{f}$ & $\ldots$ \\
\hline Mean & 72 & 81 & 68 & 67 & 44 & 18 \\
\hline $\operatorname{LSD}(P=0.05)$ & 19 & 14 & 21 & 15 & 28 & 25 \\
\hline
\end{tabular}

${ }^{x}$ Each value is the mean of five replicate plants from each of two different experiments conducted in 1994 or 1995. Citrus rootstocks in 1994 and 1995 were 5 to 11 and 5 to 6 months old, respectively, at the beginning of each trial. Numbers in each column with a different letter are significantly different $(P=0.05)$ according to the Duncan-Waller $k$-ratio (LSD) test.

y Percent reduction of root and shoot weight was determined by comparing the fresh weight of roots or shoots of each rootstock inoculated with $P$. parasitica to that of the average root or shoot fresh weight of noninoculated plants of the same rootstock.

${ }^{\mathrm{z}}$ Percent reduction of plant survival was determined by comparing the time in days from planting in potting mix to death of each rootstock inoculated with $P$. parasitica to the survival time of noninoculated plants of the same rootstock. Experiments were terminated 120 days after inoculation of rootstocks, and all noninoculated plants were alive at that time. 
Sunki mandarin $\times$ Flying Dragon trifoliate (62-109-19), African shaddock $\times$ Rubidoux trifoliate, and Shekwasha mandarin $\times$ English trifoliate was significantly less than that recorded for all other tested rootstocks. Mean shoot weights of seedlings inoculated with $P$. parasitica were 32 to $91 \%$ lower than corresponding controls. The average reduction in time of survival during the same years for rootstocks inoculated with $P$. parasitica ranged from 0 to $86 \%$ less than comparable control plants (Table 3).

Rootstocks that sustained a low percentage of root loss in the presence of $P$. citrophthora or $P$. parasitica generally experienced a low percentage of shoot loss and survived longer than severely diseased rootstocks. There was a significant linear relationship between root weight reduction and shoot weight reduction for plants inoculated with either pathogen in 1994 and $1995(P<0.001$, and coefficients of determination $\left[R^{2}\right]$ ranged from 0.522 to 0.833). Additionally, a significant linear relationship was observed between root weight reduction and plant survival time for citrus rootstocks inoculated with $P$. citrophthora in 1994 and 1995 and P. parasitica in 1994 ( $P$ ranged from $<0.001$ to 0.002 , and $R^{2}$ ranged from 0.324 to 0.523 ), whereas no significant relationship was observed between these parameters for plants inoculated with P. parasitica in 1995 $\left(P=0.087, R^{2}=0.113\right)$. The magnitude of reduction in root weight, shoot weight, and plant survival for rootstocks inoculated with P. citrophthora (74, 70, and 41\%, respectively) did not differ significantly from values recorded for plants inoculated with $P$. parasitica $(76,68$, and $31 \%$, respectively).

The average differences in the percent reduction of root weight, shoot weight, and plant survival recorded in 1994 compared with 1995 for the nine rootstocks tested in both years and inoculated with $P$. citrophthora were 14,0 , and 10 percentage points, respectively; whereas differences for the same years on plants inoculated with $P$. parasitica were 9,1 , and 25 percentage points, respectively. The differences in each parameter between 1994 and 1995 were not significantly different except for the difference in plant survival for rootstocks inoculated with $P$. parasitica, which was significant $(P=0.05)$.

The magnitude of recorded reductions in root weight, shoot weight, or plant survival for certain individual rootstocks varied considerably between 1994 and 1995. For rootstocks inoculated with $P$. citrophthora or $P$. parasitica, differences exceeding 30 percentage points for root or shoot weight reduction occurred on $C$. volkameriana and Sunki mandarin $\times$ Flying Dragon trifoliate (62-109-19), whereas differences in plant survival of the same size between 1994 and 1995 were recorded on rough lemon, Carrizo citrange, Sacaton citrumelo, and Rangpur lime $\times$ Shekwasha mandarin.

Temperatures of the potting mix recorded in the greenhouse during the course of the root rot resistance trials ranged from 11 to $38^{\circ} \mathrm{C}$ in 1994 and from 10 to $41^{\circ} \mathrm{C}$ in 1995 , with average values of 21 and $23^{\circ} \mathrm{C}$ for these 2 years, respectively. Similar ranges and average values were recorded for air temperature.

Resistance to gummosis. Control plants of each rootstock did not develop any stem lesions. The mean length of stem cankers caused by $P$. citrophthora on rootstocks examined in 1993, 1994, and 1996 ranged from 8.0 to $24.3,0.2$ to 18.1 , and 1.6 to $25.0 \mathrm{~mm}$, respectively (Table 4). Depend-

Table 4. Development of stem lesions on citrus rootstocks inoculated with mycelium of Phytophthora citrophthora

\begin{tabular}{|c|c|c|c|}
\hline \multirow[b]{2}{*}{ Rootstock } & \multicolumn{3}{|c|}{ Length of stem canker $(\mathrm{mm})^{\mathrm{z}}$} \\
\hline & 1993 & 1994 & 1995 \\
\hline \multicolumn{4}{|l|}{ Lemon types } \\
\hline Citrus macrophylla & $8.4 \mathrm{a}$ & & \\
\hline C. volkameriana & $11.3 \mathrm{a}$ & $2.8 \mathrm{a}-\mathrm{d}$ & $13.3 \mathrm{de}$ \\
\hline Rough lemon & $20.2 \mathrm{~b}$ & $2.0 \mathrm{a}-\mathrm{c}$ & $25.0 \mathrm{~g}$ \\
\hline Soh Jalia rough lemon (58-329-502) & $\ldots$ & $1.5 \mathrm{a}-\mathrm{c}$ & $4.9 \mathrm{a}$ \\
\hline Gomiri rough lemon $(62-437-501)$ & $\ldots$ & $2.2 \mathrm{a}-\mathrm{c}$ & $16.4 \mathrm{ef}$ \\
\hline \multicolumn{4}{|l|}{ Trifoliate and trifoliate hybrid types } \\
\hline Troyer citrange & $8.6 \mathrm{a}$ & 7.4 ef & $\ldots$ \\
\hline Sunki mandarin $\times$ Flying Dragon trifoliate $(\mathrm{RN}-94-20)$ & $\ldots$ & $1.9 \mathrm{a}-\mathrm{c}$ & $\ldots$ \\
\hline Rangpur lime $\times$ Marks trifoliate $($ RN-94-22) & $\ldots$ & $2.6 \mathrm{a}-\mathrm{c}$ & $\ldots$ \\
\hline Rangpur lime $\times$ Marks trifoliate $(\mathrm{RN}-94-23)$ & $\ldots$ & $2.8 \mathrm{a}-\mathrm{d}$ & $\ldots$ \\
\hline C-35 citrange & $\ldots$ & $0.2 \mathrm{a}$ & $4.0 \mathrm{a}$ \\
\hline Shekwasha mandarin × English trifoliate $(62-137-2)$ & $\ldots$ & $1.1 \mathrm{ab}$ & $3.2 \mathrm{a}$ \\
\hline Sunki mandarin $\times$ Flying Dragon trifoliate $(62-109-19)$ & $\ldots$ & $1.4 \mathrm{a}-\mathrm{c}$ & $2.3 \mathrm{a}$ \\
\hline African shaddock $\times$ Rubidoux trifoliate & $\ldots$ & $2.6 \mathrm{a}-\mathrm{c}$ & $4.6 \mathrm{a}$ \\
\hline Carrizo citrange & $\ldots$ & $4.0 \mathrm{~cd}$ & $6.2 \mathrm{a}-\mathrm{c}$ \\
\hline Sacaton citrumelo (56-70-2) & $\ldots$ & $18.1 \mathrm{~h}$ & $6.1 \mathrm{a}-\mathrm{c}$ \\
\hline Citrumelo 80-8 & $\ldots$ & $\ldots$ & $1.6 \mathrm{a}$ \\
\hline Rich 16-6 trifoliate & $\ldots$ & $\ldots$ & $4.4 \mathrm{a}$ \\
\hline Benton citrange & $\ldots$ & $\ldots$ & $5.3 \mathrm{ab}$ \\
\hline Citrumelo 4475 & $\ldots$ & $\ldots$ & $5.3 \mathrm{ab}$ \\
\hline \multicolumn{4}{|l|}{ Sour and sweet orange types } \\
\hline Sour orange & $8.0 \mathrm{a}$ & $\ldots$ & $\ldots$ \\
\hline Pineapple sweet orange & $24.3 \mathrm{~b}$ & $\ldots$ & $\ldots$ \\
\hline Goutou no. 1 sour orange & $\ldots$ & $2.3 \mathrm{a}-\mathrm{c}$ & $\ldots$ \\
\hline Oklawaha sour orange & $\ldots$ & $3.8 \mathrm{~b}-\mathrm{d}$ & $\ldots$ \\
\hline Smooth Flat Seville sour orange & $\ldots$ & $5.5 \mathrm{de}$ & $6.1 \mathrm{a}-\mathrm{c}$ \\
\hline Zhu Luan sour orange & $\ldots$ & $\ldots$ & $5.5 \mathrm{ab}$ \\
\hline \multicolumn{4}{|l|}{ Grapefruit and pummelo hybrid types } \\
\hline Rangpur lime $\times$ Kao Phung shaddock (59-121-15) & $\ldots$ & $12.1 \mathrm{~g}$ & $18.9 \mathrm{f}$ \\
\hline CRC 343 grapefruit & $\ldots$ & $\ldots$ & $13.6 \mathrm{de}$ \\
\hline \multicolumn{4}{|l|}{ Mandarin and mandarin hybrid types } \\
\hline Savage sour orange $\times$ Cleopatra mandarin no. $1(63-191-22)$ & $\ldots$ & $3.5 \mathrm{~b}-\mathrm{d}$ & \\
\hline Sicilian sour orange $\times$ Cleopatra mandarin no. $2($ F-163-192-51) & $\ldots$ & $0.2 \mathrm{a}$ & $19.1 \mathrm{f}$ \\
\hline Rangpur lime $\times$ Shekwasha mandarin $(61-169-2)$ & $\ldots$ & 3.7 b-d & $6.2 \mathrm{a}-\mathrm{c}$ \\
\hline Savage sour orange $\times$ Cleopatra mandarin no. $2(63-191-69)$ & $\ldots$ & $\ldots$ & $3.5 \mathrm{a}$ \\
\hline Sun Chu Sha mandarin & $\ldots$ & $\ldots$ & $5.6 \mathrm{ab}$ \\
\hline Cleopatra mandarin & $\cdots$ & $\cdots$ & $9.8 \mathrm{~b}-\mathrm{d}$ \\
\hline \multicolumn{4}{|l|}{ Miscellaneous } \\
\hline C. obovoidea & $\ldots$ & $3.0 \mathrm{a}-\mathrm{d}$ & $\ldots$ \\
\hline Citremon 1449 & $\ldots$ & $6.9 \mathrm{ef}$ & $\ldots$ \\
\hline C. taiwanica & $\ldots$ & $9.0 \mathrm{f}$ & $\ldots$ \\
\hline Mean & 13.5 & 4.2 & 8.3 \\
\hline $\operatorname{LSD}(P=0.05)$ & 4.5 & 2.9 & 4.6 \\
\hline
\end{tabular}

${ }^{\mathrm{z}}$ Each value is the mean of five replicate plants from each of two different experiments conducted in 1993 , 1994, or 1996. No lesions developed on control plants that received an agar disk without mycelium of $P$. citrophthora. Citrus rootstocks in 1993, 1994, and 1996 were 4, 12, and 27 months old, respectively. Numbers in each column with a different letter are significantly different $(P=$ 0.05 ) according to the Duncan-Waller $k$-ratio (LSD) test. ing upon the experiment, stem lesions smaller than $5 \mathrm{~mm}$ in length were recorded on 21 of 36 rootstocks inoculated with $P$. citrophthora. On the other hand, stem lecorded on eight different rootstocks, inGomiri rough lemon, Sacaton citrumelo, pineapple sweet orange, Rangpur lime $x$ Kao Phung shaddock, CRC 343 grapefruit, darin no. 2 .

The length of stem cankers caused by $P$. parasitica on rootstocks tested in 1993, 1994, and 1996 ranged from 2.1 to 12.0 , 0.2 to 18.5 , and 5.1 to $15.9 \mathrm{~mm}$, respectively (Table 5). Depending upon the experiment, stem lesions smaller than $5 \mathrm{~mm}$ cluding $C$. volkameriana, rough lemon, 
in length were recorded on 14 of 36 rootstocks inoculated with $P$. parasitica. On the other hand, stem lesions at least $10 \mathrm{~mm}$ in length were recorded on 16 rootstocks, including $C$. volkameriana, rough lemon, Soh Jalia rough lemon, Gomiri rough lemon, C-35 citrange, Benton citrange, Rich 16-6 trifoliate, Goutou no. 1 sour orange, Smooth Flat Seville sour orange, Rangpur lime $\times$ Kao Phung shaddock, CRC 343 grapefruit, Savage sour orange $\times$ Cleopatra mandarin no. 1, Sicilian sour orange $\times$ Cleopatra mandarin no. 2, Sun $\mathrm{Chu}$ Sha mandarin, Cleopatra mandarin, and $C$. taiwanica.

The average lengths of stem cankers from 1993 to 1996 were 8.7 and $7.9 \mathrm{~mm}$ for all rootstocks inoculated with $P$. citrophthora and $P$. parasitica, respectively. These values were not significantly different. The average stem canker lengths for 14 rootstocks inoculated with P. citrophthora in 1994 and 1996 were 4.1 and $9.7 \mathrm{~mm}$, respectively; whereas values for the same years on plants inoculated with $P$. parasitica were 6.1 and $10.2 \mathrm{~mm}$, respectively. For each pathogen, the average length of stem canker occurring in 1996 was significantly higher $(P=0.05)$ than the average value for 1994.

The length of stem canker recorded for certain individual rootstocks varied considerably between 1994 and 1996. Differences in stem canker length of at least $10 \mathrm{~mm}$ from 1994 to 1996 were recorded for 7 of

Table 5. Development of stem lesions on citrus rootstocks inoculated with mycelium of Phytophthora parasitica

\begin{tabular}{|c|c|c|c|}
\hline \multirow[b]{2}{*}{ Rootstock } & \multicolumn{3}{|c|}{ Length of stem canker $(\mathrm{mm})^{\mathrm{z}}$} \\
\hline & 1993 & 1994 & 1995 \\
\hline \multicolumn{4}{|l|}{ Lemon types } \\
\hline Citrus macrophylla & $6.0 \mathrm{~b}$ & $\ldots$ & $\ldots$ \\
\hline C. volkameriana & $10.6 \mathrm{c}$ & $6.0 \mathrm{c}-\mathrm{e}$ & 8.6 a-e \\
\hline Rough lemon & $12.0 \mathrm{c}$ & $9.1 \mathrm{e}-\mathrm{f}$ & $15.2 \mathrm{fg}$ \\
\hline Soh Jalia rough lemon (58-329-502) & $\ldots$ & $6.1 \mathrm{c}-\mathrm{e}$ & $13.0 \mathrm{e}-\mathrm{g}$ \\
\hline Gomiri rough lemon $(62-437-501)$ & $\ldots$ & $16.8 \mathrm{gh}$ & $15.9 \mathrm{~g}$ \\
\hline \multicolumn{4}{|l|}{ Trifoliate and trifoliate hybrid types } \\
\hline Troyer citrange & $2.1 \mathrm{a}$ & $3.2 \mathrm{a}-\mathrm{c}$ & $\ldots$ \\
\hline Rangpur lime $\times$ Marks trifoliate $(\mathrm{RN}-94-22)$ & $\ldots$ & $0.2 \mathrm{a}$ & $\ldots$ \\
\hline Rangpur lime $\times$ Marks trifoliate $(\mathrm{RN}-94-23)$ & $\ldots$ & $1.1 \mathrm{ab}$ & $\ldots$ \\
\hline Sunki mandarin $\times$ Flying Dragon trifoliate $(\mathrm{RN}-94-20)$ & $\ldots$ & $3.5 \mathrm{a}-\mathrm{d}$ & $\ldots$ \\
\hline C-35 citrange & $\ldots$ & $0.3 \mathrm{a}$ & $14.5 \mathrm{fg}$ \\
\hline Sunki mandarin $\times$ Flying Dragon trifoliate $(62-109-19)$ & $\ldots$ & $0.5 \mathrm{a}$ & $7.5 \mathrm{a}-\mathrm{d}$ \\
\hline Carrizo citrange & $\ldots$ & $0.5 \mathrm{a}$ & $7.6 \mathrm{a}-\mathrm{d}$ \\
\hline Shekwasha mandarin $\times$ English trifoliate $(62-137-2)$ & $\ldots$ & $0.6 \mathrm{a}$ & $8.0 \mathrm{a}-\mathrm{d}$ \\
\hline African shaddock $\times$ Rubidoux trifoliate & $\ldots$ & 4.9 a-e & $5.7 \mathrm{a}$ \\
\hline Sacaton citrumelo $(56-70-2)$ & $\ldots$ & $8.3 \mathrm{~d}-\mathrm{f}$ & $8.0 \mathrm{a}-\mathrm{d}$ \\
\hline Citrumelo 4475 & $\ldots$ & $\ldots$ & $5.4 \mathrm{a}$ \\
\hline Citrumelo 80-8 & $\ldots$ & $\ldots$ & $6.6 \mathrm{ab}$ \\
\hline Benton citrange & $\ldots$ & $\ldots$ & $13.0 \mathrm{e}-\mathrm{g}$ \\
\hline Rich 16-6 trifoliate & $\ldots$ & $\ldots$ & $13.6 \mathrm{fg}$ \\
\hline \multicolumn{4}{|l|}{ Sour and sweet orange types } \\
\hline Pineapple sweet orange & $6.8 \mathrm{~b}$ & $\ldots$ & $\ldots$ \\
\hline Sour orange & $7.4 \mathrm{~b}$ & $\ldots$ & $\ldots$ \\
\hline Oklawaha sour orange & $\ldots$ & $8.3 \mathrm{~d}-\mathrm{f}$ & $\ldots$ \\
\hline Goutou no. 1 sour orange & $\ldots$ & $12.0 \mathrm{fg}$ & $\ldots$ \\
\hline Smooth Flat Seville sour orange & $\ldots$ & 4.8 a-e & $11.7 \mathrm{c}-\mathrm{g}$ \\
\hline Zhu Luan sour orange & $\cdots$ & $\ldots$ & $6.1 \mathrm{a}$ \\
\hline \multicolumn{4}{|l|}{ Grapefruit and pummelo hybrid types } \\
\hline Rangpur lime $\times$ Kao Phung shaddock (59-121-15) & $\ldots$ & $18.5 \mathrm{~h}$ & $4.9 \mathrm{a}$ \\
\hline CRC 343 grapefruit & $\ldots$ & $\ldots$ & $12.0 \mathrm{~d}-\mathrm{g}$ \\
\hline \multicolumn{4}{|l|}{ Mandarin and mandarin hybrid types } \\
\hline Savage sour orange $\times$ Cleopatra mandarin no. $1(63-191-22)$ & $\ldots$ & $13.0 \mathrm{fg}$ & $\ldots$ \\
\hline Sicilian sour orange $\times$ Cleopatra mandarin no. $2(\mathrm{~F}-163-192-51)$ & $\ldots$ & $3.6 \mathrm{a}-\mathrm{d}$ & $14.2 \mathrm{fg}$ \\
\hline Rangpur lime $\times$ Shekwasha mandarin $(61-169-2)$ & $\ldots$ & $5.7 \mathrm{~b}-\mathrm{e}$ & $7.4 \mathrm{a}-\mathrm{c}$ \\
\hline Savage sour orange $\times$ Cleopatra mandarin no. 2 (63-191-69) & $\ldots$ & $\ldots$ & $5.1 \mathrm{a}$ \\
\hline Sun Chu Sha mandarin & $\ldots$ & $\ldots$ & $10.7 \mathrm{~b}-\mathrm{f}$ \\
\hline Cleopatra mandarin & $\ldots$ & $\ldots$ & $13.1 \mathrm{e}-\mathrm{g}$ \\
\hline \multicolumn{4}{|l|}{ Miscellaneous } \\
\hline C. obovoidea & $\ldots$ & $3.3 \mathrm{a}-\mathrm{c}$ & $\ldots$ \\
\hline Citremon 1449 & $\ldots$ & 4.4 a-e & $\ldots$ \\
\hline C. taiwanica & $\ldots$ & $14.9 \mathrm{gh}$ & $\ldots$ \\
\hline Mean & 7.5 & 6.2 & 9.9 \\
\hline $\operatorname{LSD}(P=0.05)$ & 3.1 & 4.8 & 4.6 \\
\hline
\end{tabular}

${ }^{\mathrm{z}}$ Each value is the mean of five replicate plants from each of two different experiments conducted in 1993, 1994, or 1996. No lesions developed on control plants that received an agar disk without mycelium of P. parasitica. Citrus rootstocks in 1993, 1994, and 1996 were 4, 12, and 27 months old, respectively. Numbers in each column with a different letter are significantly different $(P=$ 0.05 ) according to the Duncan-Waller $k$-ratio (LSD) test.

14 rootstocks inoculated with $P$. citrophthora or $P$. parasitica, including $C$. volkameriana, rough lemon, Gomiri rough lemon, C-35 citrange, Sacaton citrumelo, Rangpur lime $\times$ Kao Phung shaddock, and Sicilian sour orange $\times$ Cleopatra mandarin no. 2.

Nursery characteristics of citrus rootstocks. Height of seedling rootstock cultivars ranged from almost $80 \mathrm{~cm}$ (Gomiri rough lemon) to as little as $13 \mathrm{~cm}$ (Savage sour orange $\times$ Cleopatra mandarin no. 1 ) in the 10-month period between seed planting and evaluation (Table 6). Amount of growth by $C$. volkameriana $(65 \mathrm{~cm})$ was not significantly different from that of Gomiri rough lemon or Benton citrange. Soh Jalia and Milam lemon seedlings were significantly shorter than their other lemon counterparts. Most of the trifoliate hybrid rootstocks ranged from 37 to $55 \mathrm{~cm}$ in height, with only Sacaton citrumelo significantly smaller than most other trifoliates at almost $27 \mathrm{~cm}$. Grapefruit, sour orange, sour orange hybrids, and mandarin hybrid seedling rootstocks were among the smallest rootstocks, with the Cleopatra mandarin $\times$ sour orange hybrids being the smallest. Degree of branching did not appear to be related to growth, although some of the smallest seedlings had almost no branching, presumably because they had not yet reached the point where apical dominance had given way to more lateral growth by the abscission of the terminal bud (8). Among eight of the nine tallest seedlings, such as Gomiri rough lemon, $C$. volkameriana, Benton citrange, and others, the degree of branching was relatively low (0 to $14 \%$, Table 6 ) and not significantly different, which indicated a high degree of juvenility. Only Kao Pan shaddock $x$ Swingle trifoliate hybrid seedling rootstocks were among the taller cultivars tested and had significantly more branching $(27 \%)$ than the other eight tallest selections. Milam lemon and Sacaton citrumelo had 72 and $77 \%$ branching, respectively, indicating a lessening of juvenility.

Leaf chlorophyll level was greatest in Benton citrange and CRC 343 grapefruit seedlings, and was four times the level found in the Sunki mandarin $\times$ Flying Dragon trifoliate orange hybrid. In general, those trifoliate seedlings, or seedlings with trifoliate or mandarin parentage, were more chlorotic than the other seedlings tested. Exceptions to this generalization were Benton citrange, Carrizo citrange, and Rangpur lime $\times$ Shekwasha mandarin. Sour orange or sour orange type, such as Goutou of Zhu Luan, generally had more chlorophyll than the trifoliates. Smooth Flat Seville had a lower chlorophyll level than did the other sour orange types. Finally, most of the lemon type rootstocks had average to higher-than-average chlorophyll levels, excepting Soh Jalia, which was lower. 


\section{DISCUSSION}

The purpose of these studies was to screen young citrus rootstocks to identify those that were highly resistant to root rot and gummosis caused by $P$. citrophthora and $P$. parasitica, were suited to the alkaline soils of Arizona, and had superior nursery growth characteristics. None of the tested rootstocks totally fulfilled these criteria; however, a few cultivars demonstrated promising qualities with respect to nursery growth and resistance to gummosis or root rot caused by $P$. citrophthora or $P$. parasitica, warranting additional study. This group of rootstocks includes $C$. volkameriana, Gomiri rough lemon, C-35 citrange, Carrizo citrange, Kao Pan shaddock $\times$ Swingle trifoliate, Benton citrange, African shaddock $\times$ Rubidoux trifoliate, Citrumelo 4475, Goutou no. 1 sour orange, Zhu Luan sour orange, Rangpur lime $x$ Shekwasha mandarin, and Sun Chu Sha mandarin. Another group of citrus rootstocks, including C. macrophylla, rough lemon, Troyer citrange, and Rangpur lime $\times$ Marks trifoliate, were not evaluated with respect to nursery growth but did perform well in some of the root rot and gummosis trials and merit further evaluation as well. Concurrent screening of citrus rootstocks for disease resistance and nursery characteristics facilitates early identification of potentially useful plant material so that subsequent studies can focus only on those selections showing promise.

Several of the rootstocks tested currently are used in commercial citrus orchards. $C$. macrophylla, C. volkameriana, and rough lemon are well-known in Arizona and are used primarily as lemon rootstocks. Sour orange, Troyer citrange, Carrizo citrange, and C-35 citrange are used to a lesser extent in plantings other than lemons. In the field, trees established on C. macrophylla, sour orange, and the citrange rootstocks generally are resistant to root rot and gummosis caused by $P$. citrophthora and $P$. parasitica. Ratings of these three rootstocks in this study with respect to gummosis as well as the demonstrated resistance of $C$. macrophylla to root rot are in agreement with field observations. On the other hand, the relative susceptibility of sour orange and the citrange rootstocks to root rot caused by both species of Phytophthora demonstrated in our evaluations conflicts with the performance of these rootstocks in commercial orchards. Citrus orchards established on C. volkameriana in Arizona are somewhat tolerant to Phytophthora root rot and gummosis, whereas those established on rough lemon are considered to be susceptible to these diseases. In contrast to these observations, there were no conclusive differences between $C$. volkameriana and rough lemon in our greenhouse and growth chamber studies.

Conflicting classification of some citrus rootstocks with respect to susceptibility or resistance to Phytophthora have been pub- lished. In one report (31), trifoliate orange, Cleopatra mandarin, and sour orange are said to be highly resistant to infection by Phytophthora. In another publication (34), trifoliate orange, sour orange, and Carrizo citrange were considered tolerant; however, Cleopatra mandarin was categorized as susceptible to Phytophthora root rot. In a third report (13), trifoliate orange was considered tolerant, whereas Cleopatra mandarin, sour orange, and Carrizo citrange were classified as susceptible to root rot caused by $P$. parasitica. Comparing all three reports, trifoliate orange consistently is judged highly tolerant to infection by Phytophthora; whereas Cleopatra mandarin, Carrizo citrange, and sour orange could be considered either susceptible or highly tolerant.

There are several possible explanations for these apparently contradictory findings. Firstly, susceptibility or resistance with respect to gummosis may be erroneously assumed to apply to root rot as well. It is necessary to evaluate rootstocks with respect to both root rot and gummosis since our data as well as those of others $(12,14,15)$ demonstrate that resistance to root rot generally is less than resistance to bark infection. Secondly, susceptibility or resistance of citrus rootstocks to one species of Phytophthora may not be similar to the response to a different species of Phytophthora, although there was no significant difference in the severity of root rot and gummosis caused by $P$. citrophthora or

$P$. parasitica in our studies. Thirdly, the development of Phytophthora root rot or gummosis is influenced by several variables in addition to the innate resistance of the citrus host. These variables include the age, nutrient status, succulence, vigor, and scion of the infected rootstock as well as soil characteristics and soil temperature and moisture levels $(2,4,18,21,23)$, all of which affect the physiological status of the host plant. Perhaps one or more of these factors could account for the yearly variability in the extent of root rot and stem canker development that we recorded for some rootstocks tested in two different years. Also, differing ages of plants, which were 12 and 27 months old in 1994 and 1996, respectively, may partially account for the significantly larger lesions developing in 1996 compared with 1994 in our stem canker evaluation experiments. Finally, different selections of several Citrus spp. and citrus hybrids could display markedly different levels of resistance to colonization by Phytophthora. Tuzcu et al. (33) reported significant variation in resistance among selections of sour orange and trifoliate orange to colonization by $P$. citrophthora. To compensate for the influence of these variables on disease resistance ratings, data from several short-term laboratory, greenhouse, or field trials conducted under different experimental conditions with plants differing in age, nutrient status, and vigor should be compiled to arrive at a consensus determination of re-

Table 6. Growth, branching percentage, and leaf chlorophyll content of selected rootstock cultivars

\begin{tabular}{|c|c|c|c|}
\hline Rootstock type and cultivar & $\begin{array}{c}\text { Height } \\
(\mathbf{c m})\end{array}$ & $\begin{array}{c}\text { Branching } \\
(\%)\end{array}$ & $\begin{array}{l}\text { Chlorophyl } \\
\text { (mg/g f.w.) }\end{array}$ \\
\hline \multicolumn{4}{|l|}{ Lemon types } \\
\hline Gomiri rough lemon $(62-437-501)^{\mathrm{z}}$ & $76.9 \mathrm{a}$ & $7.5 \mathrm{a}-\mathrm{b}$ & $0.93 \mathrm{c}-\mathrm{j}$ \\
\hline Citrus volkameriana & $65.3 \mathrm{a}-\mathrm{b}$ & $9.0 \mathrm{a}-\mathrm{b}$ & $1.16 \mathrm{~b}-\mathrm{f}$ \\
\hline Soh Jalia rough lemon & $41.4 \mathrm{~d}-\mathrm{f}$ & $59.5 \mathrm{e}-\mathrm{f}$ & $0.67 \mathrm{i}-\mathrm{k}$ \\
\hline Milam lemon & $40.9 \mathrm{~d}-\mathrm{f}$ & $72.5 \mathrm{f}-\mathrm{g}$ & $1.08 \mathrm{~b}-\mathrm{h}$ \\
\hline \multicolumn{4}{|l|}{ Trifoliate and trifoliate hybrid types } \\
\hline Benton citrange & $54.6 \mathrm{~b}-\mathrm{c}$ & $14.0 \mathrm{~b}-\mathrm{c}$ & $1.61 \mathrm{a}$ \\
\hline C-35 citrange & $51.1 \mathrm{c}-\mathrm{d}$ & $5.0 \mathrm{a}-\mathrm{b}$ & $0.87 \mathrm{e}-\mathrm{j}$ \\
\hline Citrumelo 4475 (Swingle) & $50.0 \mathrm{c}-\mathrm{d}$ & $5.5 \mathrm{a}-\mathrm{b}$ & $0.94 \mathrm{c}-\mathrm{j}$ \\
\hline Sunki mandarin $\times$ Flying Dragon trifoliate $(62-109-19)$ & $46.0 \mathrm{c}-\mathrm{e}$ & $5.5 \mathrm{a}-\mathrm{b}$ & $0.40 \mathrm{k}$ \\
\hline Kao Pan shaddock $\times$ Swingle trifoliate & $45.5 \mathrm{c}-\mathrm{e}$ & $27.0 \mathrm{c}$ & $1.20 \mathrm{~b}-\mathrm{e}$ \\
\hline Carrizo citrange & $44.4 \mathrm{c}-\mathrm{e}$ & $3.0 \mathrm{a}-\mathrm{b}$ & $1.29 \mathrm{a}-\mathrm{c}$ \\
\hline African shaddock $\times$ Rubidoux trifoliate & $43.7 \mathrm{c}-\mathrm{e}$ & $11.5 \mathrm{a}-\mathrm{b}$ & $0.89 \mathrm{~d}-\mathrm{j}$ \\
\hline Shekwasha mandarin $\times$ English trifoliate $(62-137-2)$ & $39.1 \mathrm{~d}-\mathrm{h}$ & $2.0 \mathrm{a}-\mathrm{b}$ & $0.60 \mathrm{j}-\mathrm{k}$ \\
\hline Citrumelo $80-8$ & $37.3 \mathrm{e}-\mathrm{i}$ & $1.0 \mathrm{a}-\mathrm{b}$ & $0.92 \mathrm{~d}-\mathrm{j}$ \\
\hline Sacaton citrumelo (56-70-2) & $26.9 \mathrm{~h}-\mathrm{j}$ & $77.5 \mathrm{~g}$ & $0.76 \mathrm{~g}-\mathrm{j}$ \\
\hline \multicolumn{4}{|l|}{ Sour orange types } \\
\hline Zhu Luan & $36.3 \mathrm{e}-\mathrm{i}$ & $0.5 \mathrm{a}$ & $1.00 \mathrm{c}-\mathrm{j}$ \\
\hline Goutou no. 1 sour orange & $29.7 \mathrm{f}-\mathrm{j}$ & $3.0 \mathrm{a}-\mathrm{b}$ & $1.25 \mathrm{~b}-\mathrm{c}$ \\
\hline Smooth Flat Seville & $28.2 \mathrm{~g}-\mathrm{j}$ & $0.0 \mathrm{a}$ & $0.74 \mathrm{~h}-\mathrm{k}$ \\
\hline Oklawaha sour orange & $26.7 \mathrm{i}-\mathrm{j}$ & $0.0 \mathrm{a}$ & $1.16 \mathrm{~b}-\mathrm{f}$ \\
\hline \multicolumn{4}{|l|}{ Grapefruit and pummelo hybrid types } \\
\hline Rangpur lime $\times$ Kao Phuang shaddock (59-121-15) & $41.1 \mathrm{~d}-\mathrm{f}$ & $69.0 \mathrm{e}-\mathrm{g}$ & $1.22 \mathrm{~b}-\mathrm{d}$ \\
\hline CRC 343 grapefruit & $30.7 \mathrm{f}-\mathrm{j}$ & $56.0 \mathrm{e}^{2}$ & $1.39 \mathrm{a}-\mathrm{b}$ \\
\hline \multicolumn{4}{|l|}{ Mandarin and mandarin hybrid types } \\
\hline Rangpur lime $\times$ Shekwasha mandarin (61-169-2) & $39.6 \mathrm{~d}-\mathrm{g}$ & $41.0 \mathrm{~d}$ & $1.39 \mathrm{a}-\mathrm{b}$ \\
\hline Sun Chu Sha mandarin & $27.9 \mathrm{~g}-\mathrm{j}$ & $0.0 \mathrm{a}$ & $1.12 \mathrm{~b}-\mathrm{g}$ \\
\hline Cleopatra mandarin & $25.6 \mathrm{i}-\mathrm{j}$ & $0.0 \mathrm{a}$ & $0.92 \mathrm{~d}-\mathrm{j}$ \\
\hline Savage sour orange $\times$ Cleopatra mandarin no. $2(63-191-69)$ & $23.1 \mathrm{j}-\mathrm{k}$ & $7.0 \mathrm{a}-\mathrm{b}$ & $0.85 \mathrm{f}-\mathrm{j}$ \\
\hline Savage sour orange $\times$ Cleopatra mandarin no. $1(63-191-22)$ & $13.0 \mathrm{k}$ & $0.0 \mathrm{a}$ & $0.82 \mathrm{f}-\mathrm{j}$ \\
\hline
\end{tabular}

${ }^{\mathrm{z}}$ Numbers in parentheses correspond to original USDA-Indio accession numbers. 
sistance or susceptibility to Phytophthora root rot and gummosis.

A variety of methods have been used in the past to determine the susceptibility of citrus rootstocks to Phytophthora species, including infestation of steam-pasteurized soil with cornmeal-sand inoculum containing pathogenic isolates of Phytophthora (2), growth of plants in aerated water with added propagules of Phytophthora (20), inoculation of wounded stems (19), planting in infested field sites (18), infesting soil with mycelia of $P$. citrophthora or $P$. parasitica followed by periodic waterlogging of pots (14), inoculation of wounded (35) or nonwounded seedlings with zoospores (3), and growth of citrus cultivars in pasteurized soil amended with chlamydospores of $P$. parasitica produced in culture (13). The procedures that we employed were modified versions of some of these previously described techniques. The aim of all of these approaches was to introduce the pathogen to the host in an environment conducive to disease development.

Results of our citrus rootstock seedling nursery characteristics trial are not entirely unexpected. Of the lemon type rootstocks, Gomiri rough lemon and $C$. volkameriana are quite vigorous (11) and would be expected to have a relatively high growth rate and minimal branching, indicating a high degree of juvenility (28). Although $C$. volkameriana is well-known in Arizona, these results suggest that further study of Gomiri rough lemon may be warranted. From a nursery standpoint, both Soh Jalia lemon and Milam lemon appear to be less desirable. Growth of both rootstocks was comparatively small. The reduced vigor of these two rootstocks also may be reflected by the high degree of branching. For Milam lemon, our results agree with findings in Florida, where this rootstock appears to lack vigor in the first 2 years and requires additional care in the nursery (6), possibly because it is considered to be a hybrid. The same may be true of the Soh Jalia rough lemon. The relative lack of chlorophyll in the Soh Jalia lemon also suggests that this rootstock may differ significantly from the other lemon types.

Among the trifoliate hybrids, Benton citrange was superior to several others due to its high degree of growth, moderate branching, and high chlorophyll level. Our results lend credence to Florida data suggesting that orange trees on Benton citrange rootstock may be higher yielding than those on Carrizo citrange, with similar fruit quality (6). Most of the other trifoliate hybrids were generally quite similar to each other in growth and branching. Chlorophyll contents of the trifoliates were similar to each other as well, excepting the Sunki mandarin $\times$ Flying Dragon trifoliate and the Shekwasha mandarin $\times$ English trifoliate. This may be because of the relative lack of adaptability to calcareous soils by the trifoliate parent of these hybrids. The Flying Dragon trifoliate and the English trifoliate may be more sensitive to calcareous soils than the trifoliate parents of the other trifoliate hybrids tested here. Of the trifoliate hybrids, the most notable poor performer was the Sacaton citrumelo. Although this trifoliate hybrid originated in Arizona, our data suggest that it may perform poorly in the chief citrus growing area of the state.

The growth similarity of the sour orange type and grapefruit rootstocks was not surprising. Literature from other citrus growing areas suggests that these are quite similar (5). All were generally less vigorous than were the trifoliate hybrids, and the sour orange types usually had less branching. Both of the grapefruit-type rootstocks appeared to move quickly out of juvenility, as shown by their high degree of branching. This is an undesirable characteristic for rootstocks being considered for commercial use. Chlorophyll content among the sour orange and grapefruit types was similar, excepting Smooth Flat Seville, which was significantly less than the others. Considering that Castle et al. (5) noted micronutrient deficiencies with this rootstock at one Florida site where soil $\mathrm{pH}$ was 8.0, iron chlorosis could be a problem in Arizona.

Finally, the mandarin and mandarin hybrid rootstocks in the nursery trial had widely varying characteristics. The minimal growth and low chlorophyll levels of the tested Cleopatra mandarin hybrids call their adaptability to desert growing conditions into question. Likewise, the Rangpur lime $\times$ Shekwasha mandarin had excessive branching, so it may not be particularly valuable in the nursery industry. Nonetheless, the growth and high chlorophyll level of the Rangpur lime $\times$ Shekwasha mandarin reflect characteristics of the Rangpur lime parent, so further evaluation of this promising hybrid is warranted. Sun Chu Sha mandarin may be adaptable to calcareous soils and should be evaluated further as well.

\section{ACKNOWLEDGMENTS}

This research was generously supported by the Arizona Citrus Research Council and by state and Hatch funds allocated to the Arizona Agricultural Experiment Station.

\section{LITERATURE CITED}

1. Barmore, R. L. 1980. Soil survey of the Yuma-Wellton Area - Parts of Yuma County, Arizona and Imperial County, California. United States Department of Agriculture, Soil Conservation Service.

2. Broadbent, P. 1977. Phytophthora diseases of citrus: A review. Proc. Int. Soc. Citric. 3:986998.

3. Cameron, J. W., Klotz, L. J., De Wolfe, T. A., and Soost, R. K. 1972. Estimates of the resistance of Citrus $\times$ Poncirus hybrids to feeder root infection by Phytophthora spp. by a greenhouse seedling test. Plant Dis. Rep. 56:927-931.

4. Carpenter, J. B., and Furr, J. R. 1962. Evalua- tion of tolerance to root rot caused by Phy tophthora parasitica in seedlings of citrus and related genera. Phytopathology 52:12771285 .

5. Castle, W. S., Pelosi, R. R., Youtsey, C. O., Gmitter, F. G., Lee, R. F., Powell, C. A., and Hu, X. 1992. Rootstocks similar to sour orange for Florida citrus trees. Proc. Fla. State Hortic. Soc. 105:56-60.

6. Castle, W. S., Tucker, D. P. H., Krezdorn, A. H., and Youtsey, C. O. 1993. Rootstocks for Florida Citrus. 2nd ed. University of Florida. Inst. Food Agric. Sci. Publ. SP 42.

7. Chilembwe, E. H. C., Castle, W. H., and Cantliffe, D. J. 1992. Grading, hydrating and osmotically priming seed of four citrus rootstocks to increase germination rate and seedling uniformity. J. Am. Soc. Hortic. Sci. 117:368-372.

8. Davies, F. S., and Albrigo, L. G. 1994. Citrus Crop Production Science in Horticulture, Vol. 2. J. Atherton and A. Rees, eds. CAB International, Wallingford, Oxon, UK.

9. Davis, R. M. 1982. Control of Phytophthora root and foot rot of citrus with systemic fungicides metalaxyl and phosethyl aluminum. Plant Dis. 66:218-220.

10. Fawcett, H. S. 1936. Citrus Diseases and Their Control. McGraw-Hill, New York.

11. Ferguson, L., Sakovich, N., and Roose, M. 1990. California citrus rootstocks. Univ. Calif. Div. Agric. Natl. Resour. Publ. 21477.

12. Furr, J. R., and Carpenter, J. B. 1961. Program for breeding citrus rootstocks tolerant to Phytophthora root rot. Proc. Fla. State Hortic. Soc. 74:18-23.

13. Graham, J. H. 1990. Evaluation of tolerance of citrus rootstocks to Phytophthora root rot in chlamydospore-infested soil. Plant Dis. 74:743-746.

14. Grimm, G. R., and Hutchison, D. J. 1973. A procedure for evaluating resistance of citrus seedlings to Phytophthora parasitica. Plant Dis. Rep. 57:669-672.

15. Grimm, G. R., and Hutchison, D. J. 1977 Evaluation of Citrus spp. relatives and hybrids for resistance to Phytophthora parasitica Dastur. Proc. Int. Soc. Citric. 3:863865.

16. Jeffers, S. N., and Martin, S. B. 1986. Comparison of two media selective for Phytophthora and Pythium species. Plant Dis. 70:1038-1043.

17. Klotz, L. J. 1978. Fungal, bacterial, and nonparasitic diseases and injuries originating in the seedbed and nursery orchard. Pages 1-66 in: The Citrus Industry. Vol. 4, Crop Protection. W. Reuther, E. C. Calavan, and G. F. Carman, eds. University of California Agricultural Sciences Publications, Richmond.

18. Klotz, L. J., Bitters, W. P., De Wolfe, T. A., and Garber, M. J. 1968. Some factors in resistance of citrus to Phytophthora spp. Plant Dis. Rep. 52:952-955.

19. Klotz, L. J., De Wolfe, T. A., and Wong, P.-P 1958. Influence of two varieties of Citrus scions on the pathogenicity of three isolates of Phytophthora parasitica to sweet orange rootstocks. Phytopathology 48:520-521.

20. Klotz, L. J., De Wolfe, T. A., and Wong, P.-P. 1958. Decay of fibrous roots of citrus. Phytopathology 48:616-622.

21. Matheron, M. E., and Matejka, J. C. 1989. Temporal changes in susceptibility of citrus phloem tissue to colonization of Phytophthora citrophthora and $P$. parasitica. Plant Dis. 73:408-411.

22. Matheron, M. E., and Matejka, J. C. 1990. Differential virulence of Phytophthora parasitica recovered from citrus and other plants to rough lemon and tomato. Plant Dis. 74:138-140.

23. Matheron, M. E., and Matejka, J. C. 1993 
Seasonal differences in susceptibility of three citrus rootstocks to root lesions caused by Phytophthora citrophthora and $P$. parasitica. Plant Dis. 77:729-732.

24. Matheron, M. E., and Porchas, M. 1997. Evaluation of citrus rootstocks for relative resistance to gummosis and root rot caused by Phytophthora citrophthora and $P$. parasitica. (Abstr.) Phytopathology 87:S63.

25. Matheron, M. E., Porchas, M., and Matejka, J. C. 1997. Distribution and seasonal population dynamics of Phytophthora citrophthora and $P$. parasitica in Arizona citrus orchards and effect of fungicides on tree health. Plant Dis. 81:1384-1390.

26. Matheron, M. E., Young, D. J., and Matejka, J. C. 1988. Phytophthora root and crown rot of apple trees in Arizona. Plant Dis. 72:481484.
27. Moran, R. 1982. Formulae for determination of chlorophyllous pigments extracted with $\mathrm{N}, N$-dimethyl formamide. Plant Physiol. 69:1376-1381.

28. Spiegel-Roy, P., and Goldschmidt, E. E. 1996. Biology of Citrus. Cambridge University Press, Cambridge.

29. Timmer, L. W. 1972. Management of soilborne diseases of citrus in the Lower Rio Grande Valley. J. Rio Grande Valley Hortic. Soc. 26:44-58

30. Timmer, L. W. 1973. Characteristics of $P h y$ tophthora isolates from Texas citrus orchards. J. Rio Grande Valley Hortic. Soc. 27:44-48.

31. Timmer, L. W., and Menge, J. A. 1988. Phytophthora-induced diseases. Pages 22-24 in: Compendium of Citrus Diseases. J. O. Whiteside, S. M. Garnsey, and L. W. Timmer, eds. American Phytopathological Society, St. Paul,
MN.

32. Timmer, L. W., Menge, J. A., Zitko, S. E., Pond, E., Miller, S. A., and Johnson, E. L. 1993. Comparison of ELISA techniques and standard isolation methods for Phytophthora detection in citrus orchards in Florida and California. Plant Dis. 77:791-796.

33. Tuzcu, O., Cinar, A., Goksedef, M. O., Ozsan, M., and Bicici, M. 1984. Resistance of citrus rootstocks to Phytophthora citrophthora during winter dormancy. Plant Dis. 68:502-505.

34. University of California. 1991. Integrated Pest Management for Citrus. 2nd ed. Division of Agriculture and Natural Resources, Publ 3303. Oakland, CA

35. Whiteside, J. O. 1974. Zoospore inoculation techniques for determining the relative susceptibility of citrus rootstocks to foot rot Plant Dis. Rep. 58:713-717. 